\title{
Oral rutin suspension intervene in hepatic hyperplasia in rats
}

\author{
Pedro Paulo BARROS ${ }^{1}$, André Bernardo de Camargo EISINGER ${ }^{1}$, \\ Gisele Mara Silva GONÇALVES ${ }^{2}$ and Gustavo Henrique da SILVA ${ }^{1}$
}

Received: 29 April 2020 Accepted: 11 June 2020

\begin{abstract}
Background - Rutin is a flavonol glycoside that can be found in a wide variety of vegetables and has activity, anti-cancer, anti-inflammatory and anti-diabetic properties. Objective - This study investigated the effect of rutin oral administration on Wistar rats submitted to hepatic hyperplasia after partial hepatectomy ( $\mathrm{PH})$. Methods - To achieve this, we considered the analysis of hepatic hyperplastic and plasma biochemical activity of Wistar rats, subjected to treatment with rutin $40 \mathrm{mg} / \mathrm{kg} / \mathrm{day}$ for 10 days in group 1 (G1) or saline in group 2 (G2), followed by partial hepatectomy. Results - The results indicated an increase in the number of mitoses after 24 hours and 48 hours $(P=0.0022$ and $P=0.0152$, respectively $)$ of $P H$ in the group that received rutin, as well as an increase in AST serum levels after 24 hours $(P=0.0159)$ and 48 hours $(P=0.0158)$ and alkaline phosphatase after 24 hours $(P=0.015)$ in the same group, in relation to the respective controls. The group that received rutin showed a more evident variation than the control group when comparing the 24 hour and 48 hour results regarding AST, number of mitoses and number of apoptosis $(P<0.005)$. Conclusion - It was concluded that rutin intervened in hepatic hyperplasia after 24 hours and 48 hours of $\mathrm{PH}$, favoring hepatic hyperplasia.
\end{abstract}

HEADINGS - Rutin. Hyperplasia. Hepatectomy. Oral suspension. Liver, drug effects. Wistar rats.

\section{INTRODUCTION}

The search for treatments that favor hepatic hyperplasia and promote a better outcome for some surgical procedures and chronic diseases has led scientists to test a wide variety of drugs. Rutin is a flavonol glycoside that can be found in a wide variety of vegetables and has activity, anti-cancer, anti-inflammatory and anti-diabetic properties $^{(1,2)}$. Regarding the liver, there are reports of potent hepatoprotective activity on the toxicity induced by paracetamol in albino Wistar rats $^{(3)}$ and on the hepatotoxicity induced by hypercholesterolemia in rats $^{(4)}$. Li et al..$^{(5)}$ demonstrated that rutin administration could intervene in inflammation, lipid accumulation, mitochondrial dysfunction and oxidative stress, that is to say, improving aging-related metabolic dysfunction.

Curcumin, hesperidin and rutin, studied in association by Parmar et al. ${ }^{(6)}$, significantly improved apoptotic signalling in rats with chemically induced diabetes and reduced hepatic oxidative stress resulting from hyperglycemia.

Chuffa et al..$^{(7)}$ studied the serums, cardiac and hepatic effects of rutin treatment "in rats subjected to a combination of a high calorie diet and chronic ethanol consumption, with rutin being effective in reducing risk factors for heart and liver disease".

Partial hepatectomy is an experimental model that has been used to evaluate the action of different phytochemicals. We did not find any research that studied the effects of rutin treatment at a dose of $40 \mathrm{mg} / \mathrm{kg} /$ day on hepatic hyperplastic activity and is commonly sold as a herbal supplement.

The aim of our study was to evaluate the effect of rutin on hepatic hyperplasia in rats after 70\% partial hepatectomy (PH). To achieve this, the analysis of hepatic hyperplastic activity and plasma biochemistry was considered.

\section{METHODS}

Wistar rats (seven-week-old) male (body weight $175.3 \pm 21 \mathrm{~g}$ ) were kept in a climate-controlled room $\left(21^{\circ} \mathrm{C} \pm 2^{\circ} \mathrm{C}\right)$ with a 12 -hour artificial light cycle. Three animals remained in each box with free access to tap water. All animals were allowed to acclimatize for a week, followed by randomization and allocation ${ }^{(8-12)}$. There were two groups $(n=12)$ : rutin group $(\mathrm{G} 1)$ received suspension 40 $\mathrm{mg}$ rutin $/ \mathrm{kg} /$ day for 10 days, prior to the performance of partial hepatectomy, administered orally (gastric gavage). Control group (G2) received saline. Committee of Ethics on the Use of Animals (CEUA) of Pontifical Catholic University of Campinas approved the experiments, protocol 020/2017.

\section{Partial hepatectomy, sample collection, euthanasia and histology}

The removal of almost $70 \%$ of the liver tissue was performed after a 12-hour fast and administering anesthesia with high dose of xylazine and ketamine solution via intraperitoneal ${ }^{(8-12)}$. A sensitivity test was performed on the lower and upper limbs before the start of the surgical procedure. 24 and 72 hours after $\mathrm{PH}$, six animals from each group were submitted to the procedures of tissue collection and blood samples and then euthanized, as described below. Postoperative analgesia of animals until euthanasia was maintained.

Declared conflict of interest of all authors: none

Disclosure of funding: no funding received

${ }_{1}^{1}$ Pontifícia Universidade Católica de Campinas, Faculdade de Ciências Farmacêuticas, Campinas, SP, Brasil. ${ }^{2}$ Pontifícia Universidade Católica de Campinas, Programa de Pós Graduação em Ciências da Saúde, Campinas, SP, Brasil.

Corresponding author: Gisele Mara Silva Gonçalves. E-mail: gmsg@puc-campinas.edu.br 
G1 was separated into G1-24 and G1-48, and G2 into G2-24 and G2-48 as a function of time between $\mathrm{PH}$ and euthanasia $(n=6)$. To paralyze the mitosis figures, an intraperitoneal injection of vincristine sulfate $1 \mathrm{mg} / \mathrm{kg}$ was used two hours before the commencement of the anesthetic procedure, which was followed by the containment of the animals, opening of the chest and puncture of the left ventricle for blood collection. Parts of the hepatic lobes were immediately collected, which were kept in $10 \%$ formaldehyde, buffered for histological and histochemical procedures (obtaining seven-micron thick stained sections with hematoxylin and eosin, in addition to Feulgen reaction. Euthanasia was performed by deepening anesthesia. All the histological analyses were performed in an optic microscope by counting the number of mitoses and apoptosis and observing the general appearance of the liver tissue $\mathrm{e}^{(8-11)}$.

\section{Biochemical analysis}

The measurements of aspartate-aminotransferase, alkaline phosphatase and alanine-aminotransferase were performed on blood serum samples using specific Laborlab ${ }^{\circledR}$ kits and spectrophotometric analysis ${ }^{(10)}$.

\section{Statistical analysis}

All results were examined for significance using Mann Whitney test, and significance was set at $P<0.05$.

\section{RESULTS}

There were no morphological changes in the hepatic histology of the analyzed samples. The statistical analysis showed significant changes from the group treated with rutin to the control group (TABLES 1, 2 and FIGURE 1). There was an increase in the number of mitoses after 24 hours and 48 hours of $\mathrm{PH}$ in the group that received rutin, as well as an increase in serum levels of aspartate aminotransferase (AST) 24-hour and 48-h of PH, and of alkaline phosphatase after 24 hours in this group.

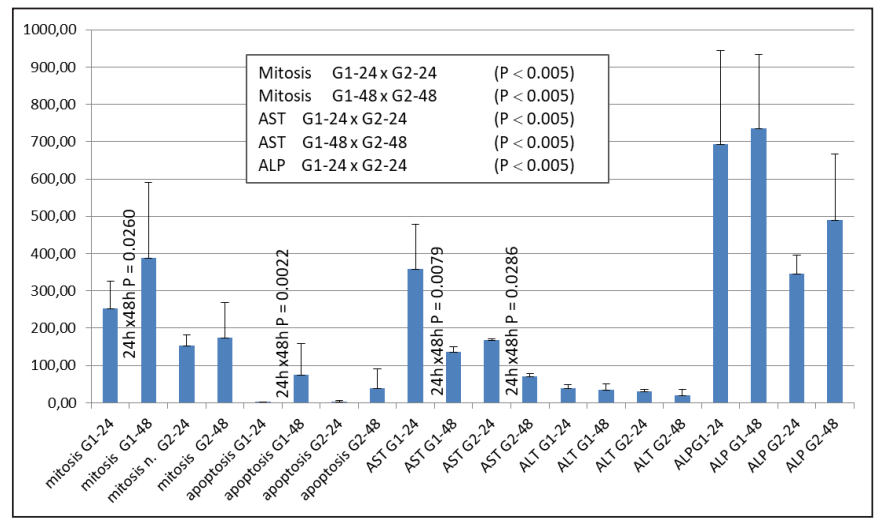

FIGURE 1. Number of mitoses, number of apoptosis, serum levels (U/L) of alanine aminotransferase (ALT), aspartate aminotransferase (AST) and alkaline phosphatase (ALP) of rats treated with rutin (G1-24 and G1-48) or saline (G2-24 and G2-48) and subjected to partial hepatectomy. Mann Whitney test $(\mathrm{n}=6)$.

\section{DISCUSSION}

The occurrence of liver diseases is high and due to the importance of this organ for the maintenance of human life, many studies have been conducted to identify new hepatoprotective drugs. Herbal compounds have long been proposed for liver treatment. We focus on knowing more about the effects of rutin supplementation could exert on liver hyperplasia when administered prior to surgery, in rats. Justifying those studies with liver resection have been carried out in rats.

Considering the survival rate of the animals, the removal of $70 \%$ of the liver tissue is an aggressive procedure that can lead to the death of the rats in a few hours. In this study, the selected rats were young (only seven-week-old) and there were no deaths corroborating the data by Enkhbold et al. ${ }^{(13)}$ who observed the survival of young animals and only $60 \%$ of older rats after $\mathrm{PH}$.

TABLE 1 . General results after $24 \mathrm{~h}$-treament period.

\begin{tabular}{ccccc}
\hline Number of mitosis & Number of Apoptosis & AST (U/L) & ALT (U/L) & Alkaline phosphatase (U/L) \\
\hline $\begin{array}{cccc}\text { Rutin treated group (G1-24) } \\
252.67 \pm 74.3^{\mathrm{a}}\end{array}$ & $1.00 \pm 0.9$ & $358.43 \pm 119.1^{\mathrm{b}}$ & $38.73 \pm 9.2$ & $692.86 \pm 250.5^{\mathrm{c}}$ \\
$\begin{array}{c}\text { Control group (G2-24) } \\
152.50 \pm 29.7\end{array}$ & $2.83 \pm 3.3$ & & & $345.56 \pm 51.3$ \\
\hline
\end{tabular}

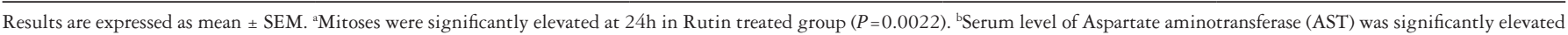
at $24 \mathrm{~h}$ in Rutin treated group $(P=0.0159)$. 'Serum level of alkaline phosphatase was significantly elevated at $24 \mathrm{~h}$ in Rutin treated group $(P=0.0159)$. Mann Whitney test ( $\mathrm{n}=6$ ).

TABLE 2. General results after 48h-treatment period.

\begin{tabular}{ccccc}
\hline Number of mitosis & Number of Apoptosis & AST (U/L) & ALT (U/L) & Alkaline phosphatase (U/L) \\
\hline $\begin{array}{cccc}\text { Rutin treated group (G1-48) } \\
387.67 \pm 202.6^{\mathrm{a}}\end{array}$ & $74.83 \pm 83.5$ & & & \\
Control group (G2-48) & & & & \\
$175.00 \pm 94.3$ & $38.50 \pm 52.7$ & $735.95 \pm 14.0^{\mathrm{b}}$ & & \\
\end{tabular}

Results are expressed as mean \pm SEM. ${ }^{a}$ Mitoses were significantly elevated at $48 \mathrm{~h}$ in Rutin treated group $(P=0.0152)$. ${ }^{b}$ Serum level of Aspartate aminotransferase (AST) was significantly elevated at $48 \mathrm{~h}$ in Rutin treated group $(P=0.0159)$. Mann Whitney test $(\mathrm{n}=6)$. 


\section{Mitosis and apoptosis}

By means of the numbers of mitoses found, it was observed that hepatic hyperplasia was ongoing in G1 and G2, as this number was significantly high when compared with data from the literature ${ }^{(14)}$. However, in the groups that received treatment with rutin (G1) there was a significant increase in the number of mitoses after 24 hours $(P=0.0022)$ and 48 hours $(P=0.0152)$, indicating that the treatment contributed to the stimulation of hyperplasia.

These results are consistent with expectations, as in acute events such as $\mathrm{PH}$, a complete process of hepatic hyperplasia begins with a view to restore the organ's weight to its original size and restore homeostasis. This process is exclusive to the liver and involves complex mechanisms with a variety of specific regenerative pathways for different types of injury ${ }^{(15,16)}$. According some authors "mitochondrial DNA, oxidative phosphorylation capacity, mitochondrial enzyme activity and subunits of energy transmitting complexes increase" within 48 hours after $\mathrm{PH}^{(16,17)}$.

As for the number of apoptosis, the statistical analysis showed no significant difference between the experimental groups. After 24 hours of PH the number of apoptosis found was lower (about 1 to 2 per observed field, on average) whereas after 48 hours of $\mathrm{PH}$ this number increased significantly (about 38 to 48 per observed field, on average). According to some authors ${ }^{(15)}$ chronic liver damage results in random and continuous death of hepatocytes, which trigger signals that lead to compensatory proliferation of viable residual hepatocytes. The type of liver injury produced by $\mathrm{PH}$ generates a regeneration process similar to that of wound healing, although hyperplasia occurs in this organ, reorganization of the lobes occurs and the liver returns to normal size ${ }^{(16)}$. According to other authors ${ }^{(18)}$ in the process of wound healing, there is a decrease in apoptosis, and supplementation with some antioxidants increase cell viability in hypoxia situations.

\section{Liver enzymes}

In this study, with regard to liver enzymes, there was only a significant increase in AST serum levels in the group treated with rutin, in relation to the control group after 24 hours $(P=0.0159)$ and after 48 hours $(P=0.0158)$ of $\mathrm{PH}$, in addition to the increase in alkaline phosphatase levels in the group treated with rutin, in relation to the control group after 24 hours $(P=0.015)$. Analyzing these results and considering the ongoing hyperplasia process, the increase in AST and alkaline phosphatase serums, without altering the number of apoptosis, indicates that the origin of these enzymes are viable cells that underwent both the rutin and the surgical procedure. Knowing that AST may come from hepatocyte mitochondria, its concentration increases after serious injuries ${ }^{(19)}$. This result corroborates with Enkhbold et al. ${ }^{(13)}$ when studying the association of aging and other factors during hepatic regeneration after hepatectomy, and finding serum levels of alanine aminotransferase (ALT), AST, total bilirubin and elevated HDL-cholesterol in the older group reflecting liver damage. Therefore, analyzing the result obtained for AST in isolation, it can be suggested that the rutin treatment did not exert a hepatoprotective effect and seems to have aggravated the hepatic medical condition.

In our study, ALT levels had not a significant change in at the time of our research or in alkaline phosphatase after 48 hours in the group treated with rutin in relation to the control group, indicating that the treatment did not intervene in these parameters. In contrast to what occurred in our study and using a different mechanism of liver damage, Shenbagam and Nalini(20) performed rutin administration at a dose of $100 \mathrm{mg} / \mathrm{kg}$ of body weight in rats treated with ethanol and found a significant reduction in serum levels of ALT and AST, concluding that rutin has a protective effect against ethanol-induced hepatotoxicity. It should be noted that the treatment time employed by these authors was longer, totaling 60 days of ethanol administration and 30 days of rutin suspensions. They used a higher dose and there may be a dose-dependent effect, which could be investigated in the future.

\section{Hepatic hyperplasia}

The term liver regeneration has been used by many authors cited throughout this work, however, it must be considered that the removal of $2 / 3$ of the liver tissue does not result in the formation of new lobes. There is an increase in size due to hyperplasia, in response to the complex intracellular mechanisms triggered by the imbalance of homeostasis generated by extensive tissue removal. Due to this compensatory activity that initially impacts the increase in mitosis, liver functionality can be maintained ${ }^{(21)}$.

Some authors ${ }^{(22)}$ studied plant extracts rich in rutin and verified agonist action on the receptor "involved in the regulation of bile acid homeostasis in liver", which could be "a promising hepatoprotective agent and a new strategy approach for cholestatic liver diseases by modulating the NF- $\chi \mathrm{B}$, and FXR signaling pathways".

In this study, we evaluated the variation of the results obtained after 24 hours and 48 hours of the $\mathrm{PH}$ to compare what occurred in this period, and the statistical analysis indicated that the control group only showed variation in the AST serum dosage when the results obtained after 24 hours and 48 hours were compared to PH, while the group treated with rutin showed variation in AST and in the number of mitoses and apoptosis (TABLE 3). There was no variation in serum levels of alkaline phosphatase and ALT. This data suggests that treatment with rutin also influenced the progression of hepatic hyperplasia, increasing the number of apoptosis and mitoses after 48 hours of $\mathrm{PH}$. As the increase in mitoses was higher after 48 hours, this is an indication that treatment with rutin may have accelerated the process of hepatic hyperplasia, and the increase in the number of apoptosis may suggest that cell death is occurring as a mechanism for controlling this process. Therefore, the increase in the number of mitoses observed in the treated group indicates that rutin by a mechanism yet to be elucidated, potentiated hepatic hyperplasia.

TABLE 3. Statistical results (Mann Whitney test) comparing the data obtained after $24 \mathrm{~h}$ and after $48 \mathrm{~h}$.

\begin{tabular}{|c|c|c|c|c|}
\hline Mitosis & Apoptosis & AST & ALT & $\begin{array}{c}\text { Alkaline } \\
\text { phosphatase }\end{array}$ \\
\hline
\end{tabular}

Treated group ( $24 \mathrm{~h}$ versus $48 \mathrm{~h}$ results)

$P=0.0260 \quad P=0.0022 \quad P=0.0079 \quad P>0.05 \quad P>0.05$

Control group (24h versus $48 \mathrm{~h}$ results)

$\begin{array}{rlrl}P>0.05 & P>0.05 & P=0.0286 \quad P>0.05 \quad P>0.05\end{array}$

\section{CONCLUSION}

Oral treatment for ten days with rutin at a dose of $40 \mathrm{mg} / \mathrm{kg} / \mathrm{day}$ in rats intervened in hepatic hyperplastic and plasma biochemical activity, demonstrated by the increase in the number of mitoses and elevation of AST after 24 hours and 48 hours of PH. 


\section{Authors' contribution}

Barros PP: author responsible for the integrity of the work. All authors Eisinger ABC, Gonçalves GMS, Silva GH were involved in the development of the research and contributed to the experimental design and treatment schedule and to the analysis of enzymatic dosages.

\section{Orcid}

Pedro Paulo Barros: 0000-0001-7435-1645.

André Bernardo de Camargo Eisinger: 0000-0002-66540339.

Gisele Mara Silva Gonçalves: 0000-0002-3480-5777.

Gustavo Henrique da Silva: 0000-0002-4277-1167.

Barros PP, Eisinger ABC, Gonçalves GMS, Silva GH. Suspensão oral de rutina interfere na hiperplasia hepática em ratos. Arq Gastroenterol. 2020;57(3):296-9.

RESUMO - Contexto - A rutina é um flavonoide que pode ser encontrado em grande variedade de vegetais e apresenta atividades anticâncer, anti-inflamatória e antidiabética. Objetivo - O objetivo deste estudo foi investigar o efeito da administração oral de rutina sobre a hiperplasia hepática em ratos Wistar submetidos à hepatectomia parcial. Métodos - Foi realizada a análise da hiperplasia hepática e da bioquímica plasmática dos ratos Wistar tratados com rutina $40 \mathrm{mg} / \mathrm{kg}$ por 10 dias no grupo $1(\mathrm{G} 1)$ ou salina no grupo $2(\mathrm{G} 2)$, seguido da hepatectomia parcial. Resultados - Os resultados indicaram aumento do número de mitoses após 24 e 48 horas ( $P=0,0022$ e $P=0,0152$, respectivamente) da hepatectomia parcial no grupo que recebeu rutina, além de um aumento nos níveis séricos de AST após 24 horas $(P=0,0159)$ e 48 horas $(P=0,0158)$ e de fosfatase alcalina após 24 horas $(P=0,015)$ no mesmo grupo, em relação aos respectivos controles. $O$ grupo que recebeu rutina mostrou variação mais evidente do que o grupo controle quando se comparou os resultados de 24 horas e 48 horas em relação a AST, número de mitoses e número de apoptoses $(P<0,005)$. Conclusão - Foi possível concluir que a rutina interferiu na hiperplasia hepática após 24 e 48 horas após a hepatectomia parcial, favorecendo a hiperplasia hepática.

DESCRITORES - Rutina. Hiperplasia. Hepatectomia. Fígado, efeitos dos fármacos. Ratos Wistar.

\section{REFERENCES}

1. Hafez MM, Al-Harbi NO, Al-Hoshani AR, Al-Hosaini KA, Al Shrari SD, Al Rejaie SS, Al-Shabanah O. A Hepato-protective effect of rutin via IL-6/STAT3 pathway in CCl4-induced hepatotoxicity in rats. Biol Res. 2015;48:30.

2. Kadota K, Semba K, Shakudo R, Sato H, Deki Y, Shirakawa Y, Tozuka Y. Inhibition of photodegradation of highly dispersed folic acid nanoparticles by the antioxidant effect of transglycosylated rutin. Agric Food Chem. 2016;64: 3062-9.

3. Reddy MK, Reddy AG, Kumar BK, Madhuri D, Boobalan G, Reddy MA Protective effect of rutin in comparison to silymarin against induced hepatotoxicity in rats. Vet World. 2017;10:74-80.

4. AlSharari SD, Al-Rejaie SS, Abuohashish HM, et al. Rutin attenuates Hepatotoxicity in high-cholesterol-diet-fed rats. Oxid Med Cell Longev. 2016;2016:5436745.

5. Li T, Chen S, Feng T, Don JLY, Li H. Rutin protects against aging-related metabolic dysfunction. Food Funct. 2016;7:1147-54

6. Parmar MS, Syed I, Gray JP, Ray SD. Curcumin, Hesperidin, And Rutin Selectively Interfere With Apoptosis Signaling And Attenuate Streptozotocin-Induced Oxidative Stress-Mediated Hyperglycemia. Curr Neurovasc Res. 2015;12: 363-74.

7. Chuffa LGA, Fioruci-Fontanelli BA, Bordon JG, Pires RB, Braga CP, Seiva FR, Fernandes AAH. A Rutin ameliorates glycemic index, lipid profile and enzymatic activities in serum, heart and liver tissues of rats fed with a combination of hypercaloric diet and chronic ethanol consumption. Indian J Biochem Biophys. 2014;51:215-22.

8. Barros PP, Gonçalves GMS, Silva GH, Bastos MCVD, Ramos LN, Fernandes MM. Lycopene and resveratrol pretreatment did not interfere with the liver of hepatectomized rats. Acta Cir. Bras. 2017;32:194-202.

9. Barros PP, Gonçalves GMS, Silva GH, Bastos MCVD, Ramos LN, Fernandes MM. Capsiate treatment in liver surgeries may compromise its recovery. Acta Cir. Bras. 2018;33:439-45

10. Barros PP, Gonçalves GMS, Silva GH, Fava ALM. Pretreatment of hepatetctomized rats with Coleus forskohlii did not interfere with the course of hepatic hyperplasia. Acta Cir. Bras. 2019;34:e201900607.
11. Barros PP, Silva GH, Gonçalves GMS, Oliveira JC, Pagnan LG, Arco-e-Flexa L. Hepatoprotective effect of quercetin pretreatment against paracetamol-induced liver damage and partial hepatectomy in rats. Braz. arch. biol. technol. 2017;60:e16160138.

12. Higgins GM, Anderson RM. Experimental pathology of the liver: I. Restoration of the liver of the white rat following partial surgical removal. Arch. Pathol. 1931;12:186-202.

13. Enkhbold C, Morine Y, Utsunomiya T, Imura S, Ikemoto T, Arakawa Y, Shimada M. Dysfunction of liver regeneration in aged liver after partial hepatectomy. J Gastroenterol Hepatol. 2015;30:1217-24

14. Soto G, Rodríguez MJ, Fuentealba R, Treuer AV, Castillo I, González DR, Zúñiga-Hernández J. Maresin 1, a Proresolving Lipid Mediator, Ameliorates Liver Ischemia-Reperfusion Injury and Stimulates Hepatocyte Proliferation in Sprague-Dawley Rats. Int J Mol Sci. 2020;21(2). pii: E540.

15. Michalopoulos GK. Hepatostat: Liver regeneration and normal liver tissue maintenance. Hepatology. 2017;65:1384-92.

16. Michalopoulos GK. Liver regeneration. J Cell Physiol. 2007;213:286-300.

17. Nagino M, Tanaka M, Nishikimi M, Nimura Y, Kubota H, Kanai M, et al. Stimulated rat liver mitochondrial biogenesis after partial hepatectomy. Cancer Res. 1989;49:4913-8.

18. Campos ACL, Borges-Branco A, Groth AK. Cicatrização de feridas. ABCD Arq Bras Cir Dig. 2007;20:51-8.

19. Costa Matos L. Doença hepática alcoólica. Med Interna. 2006;13:207-16.

20. Shenbagam $M$, Nalini N. Dose response effect of rutin a dietary antioxidant on alcohol-induced prooxidant and antioxidant imbalance-a histopathologic study. Fundam Clin Pharmacol. 2011;25:493-502.

21. Mao SA, Glorioso JM, Nyberg SL. Liver regeneration. Transl Res. 2014;163:35262. doi: 10.1016/j.trsl.2014.01.005.

22. El-Hawary SS, Ali ZY, Younis IY. Hepatoprotective potential of standardized Ficus species in intrahepatic cholestasis rat model: Involvement of nuclear factor- $x \mathrm{~B}$, and Farnesoid X receptor signaling pathways. J Ethnopharmacol. 2019;231:262-74 